\title{
Correction to: Skating on thin ice: pragmatic prescribing for medication refractory schizophrenia
}

Derek K. Tracy ${ }^{1,2^{*}}$, Dan W. Joyce ${ }^{2,3}$, S. Neil Sarkar ${ }^{2,4}$, Maria-Jesus Mateos Fernandez ${ }^{2}$ and Sukhwinder S. Shergill ${ }^{2,3}$

\author{
Correction to: BMC Psychiatry (2015) 20:48 \\ https://doi.org/10.1186/s12888-015-0559-x
}

After publication of the original article [1], the authors have notified us that there was an oversight on acknowledging funding received for the study. They would like to mention that Professor Sukhi Shergill was funded by an ERC Consolidator Award.

\section{Author details}

'Oxleas NHS Foundation Trust, Green Parks House, Orpington, London, Kent BR6 8NY, UK. ${ }^{2}$ Cognition, Schizophrenia \& Imaging Laboratory, Department of Psychosis Studies, The Institute of Psychiatry, King's College London, London, UK. ${ }^{3}$ South London and Maudsley NHS Foundation Trust, London, UK. ${ }^{4}$ Central and North West London NHS Foundation Trust, London, UK.

Received: 21 May 2019 Accepted: 21 May 2019

Published online: 27 May 2019

\section{Reference}

1. Tracy DK, et al. Skating on thin ice: pragmatic prescribing for medication refractory schizophrenia. BMC Psychiatry. 2015;20:48. https://doi.org/10.1186/ s12888-015-0559-x.

\footnotetext{
*Correspondence: derek.tracy@oxleas.nhs.uk

'Oxleas NHS Foundation Trust, Green Parks House, Orpington, London, Kent BR6 8NY, UK

${ }^{2}$ Cognition, Schizophrenia \& Imaging Laboratory, Department of Psychosis

Studies, The Institute of Psychiatry, King's College London, London, UK

Full list of author information is available at the end of the article
}

(c) The Author(s). 2019 Open Access This article is distributed under the terms of the Creative Commons Attribution 4.0 International License (http://creativecommons.org/licenses/by/4.0/), which permits unrestricted use, distribution, and reproduction in any medium, provided you give appropriate credit to the original author(s) and the source, provide a link to the Creative Commons license, and indicate if changes were made. The Creative Commons Public Domain Dedication waiver (http://creativecommons.org/publicdomain/zero/1.0/) applies to the data made available in this article, unless otherwise stated. 